\title{
PENGARUH PENYULUHAN TERHADAP TINGKAT PENGETAHUAN ANGGOTA LSM HIV-AIDS TENTANG DETEKSI DINI DAN TATALAKSANA KUTIL KELAMIN DI PUSKESMAS DINOYO KOTA MALANG
}

\author{
Anggun Putri* ${ }^{\star}$, Dhany Prafita*
}

\begin{abstract}
Abstrak
Kutil kelamin atau secara medis disebut kondilomata akuminata merupakan Infeksi Menular Seksual (IMS) yang paling umum terjadi di dunia. Kutil kelamin sebagian besar tidak akan menimbulkan gejala dan bahkan bersifat subklinis selama berbulan-bulan atau bertahun-tahun sehingga pasien tidak menyadari penyakitnya dan bahkan menularkan secara tidak sadar kepada orang lain. Program pendidikan terhadap masyarakat bertujuan untuk mengetahui pengaruh penyuluhan terhadap tingkat pengetahuan anggota Lembaga Swadaya Masyarakat (LSM) HIV-AIDS tentang deteksi dini dan tatalaksana kutil kelamin.di Puskesmas Dinoyo. Desain yang diterapkan yaitu ceramah (penyuluhan) dan diskusi dengan topik bahasan meliputi definisi, manifestasi, pola penularan, deteksi dini, dan tatalaksana kutil kelamin. Serapan materi oleh peserta penyuluhan dievaluasi dengan uji pengetahuan. Kegiatan dilakukan dalam satu hari, bertempat di Puskesmas Dinoyo, kecamatan Lowokwaru, Kota Malang dengan khalayak sasaran pasien poliklinik dan anggota LSM di bidang IMS dan HIV-AIDS. Hasil yang didapatkan adalah meningkatnya pengetahuan peserta mengenai deteksi dini dan tatalaksana kutil kelamin $(p<0,05)$. Berdasarkan pelaksanaan kegiatan penyuluhan, dapat disimpulkan bahwa pendidikan masyarakat efektif untuk meningkatkan pengetahuan para anggota LSM dan tenaga medis yang bergerak di bidang Infeksi Menular Seksual dan HIV-AIDS mengenai deteksi dini dan tatalaksana kutil kelamin. Diharapkan kegiatan ini akan memberikan bantuan keilmuan pada masyarakat mengenai kutil kelamin dan selanjutnya akan menurunkan risiko penularan serta insiden penyakit.
\end{abstract}

Kata kunci: deteksi dini, kutil kelamin, pendidikan masyarakat.

\section{EFFECT OF PUBLIC EDUCATION ON NON GOVERNMENT ORGANIZATIONS ACTIVIST'S (NGO) KNOWLEDGE LEVEL ABOUT GENITAL WART'S EARLY DETECTION AND MANAGEMENT AT DINOYO PRIMARY PUBLIC HEALTH CENTRE MALANG}

\begin{abstract}
Genital wart or known as condylomata accuminata is the most common Sexual Transmitted Disease (STD) around the world. It has minimal symptoms and even tend to be subclinic for months and even years. The minimal symptom might lead to unawareness and the patient often accidentally spreading the virus to other person. This public program is aimed to measure the effect of public education on Non Government Organizations activist's (NGO) knowledge level about genital wart's early detection and management at Dinoyo Primary Public Health Centre Malang. The chosen method was educational class followed with discussion session. The material of educational program were including definition, manifestation, infection route, early detection and management of genital wart. Participants achievement were evaluated using knowledge test about the material previously described. The program was held at Dinoyo Primary Public Health Centre, Lowokwaru, Malang with target audience namely outward pastient and HIV- AIDS Non Government Organization activist. The result showed increasing knowledge about early detection and management of genital wart $(p<0.05)$. It can be concluded that educational public program is effective to increase knowledge value of early detection and management of genital wart on HIV-AIDS NGO's activist and HIV-AIDS medical officer. This educational program was expected to increase public awareness of genital wart and minimize disease transmission and incidence.
\end{abstract}

Keywords: early detection, genital wart, public educational program.

Departemen/SMF IImu Kesehatan Kulit dan Kelamin, Fakultas Kedokteran, Universitas Brawijaya Malang

E-mail: angg_yuniaswan@yahoo.com 


\section{Pendahuluan}

Infeksi Menular Seksual (IMS) merupakan salah satu penyebab permasalahan kesehatan, sosial dan ekonomi di banyak negara. Hampir 500 juta kasus baru IMS terjadi setiap tahun di seluruh dunia. ${ }^{1}$ Banyak di antara kasus IMS tersebut merupakan penyakit yang dapat dicegah dan diobati, salah satunya yaitu kutil kelamin. Kutil kelamin atau secara medis dikenal sebagai kondiloma akuminata merupakan IMS yang paling umum terjadi di dunia. ${ }^{2,3,4}$

Laporan dari beberapa studi epidemiologi yang dilakukan di beberapa negara berkembang, termasuk Indonesia menunjukkan bahwa tingkat penularan kutil kelamin masih cukup tinggi. ${ }^{1}$ Salah satu faktor yang berperan dalam tingginya transmisi tersebut adalah rendahnya tingkat kewaspadaan terhadap kutil kelamin.

Situasi di Indonesia menurut laporan Kementrian Kesehatan menunjukkan adanya peningkatan kasus HIV-AIDS dan IMS. ${ }^{1}$ Pemerintah telah menetapkan Program Layanan Komprehensif Berkesinambungan (LKB) di bidang IMS dan HIV. Puskesmas, sebagai fasilitas layanan kesehatan primer memiliki fungsi menyelenggarakan upaya kesehatan yang bersifat menyeluruh. Puskesmas Dinoyo, sebagai salah satu puskesmas di kota Malang, memiliki layanan poliklinik IMS dan HIV-AIDS, serta memiliki akses terhadap Lembaga Swadaya Masyarakat (LSM) terkait. Sasaran strategis selain masyarakat awam, dalam program pendidikan masyarakat terkait IMS adalah anggota LSM dan tenaga medis yang bergerak di bidang IMS dan HIV-AIDS. Salah satu kebijakan pemerintah terkait pengendalian HIV-AIDS dan IMS tahun 20102014 yaitu dicanangkannya program berbasis masyarakat. Data di Puskesmas Dinoyo sebagai salah satu puskesmas rujukan untuk layanan HIV-IMS menunjukkan kutil kelamin merupakan salah satu IMS dengan prevalensi yang cukup tinggi (data tidak dipublikasi).

Masalah yang dihadapi oleh masyarakat terkait dengan kutil kelamin adalah minimnya tingkat pengetahuan terhadap cara penularan, gejala dan tatalaksana kuti kelamin. $^{2}$ Berdasarkan masalah tersebut, program pendidikan masyarakat dititik beratkan pada deteksi dini dan tatalaksana kutil kelamin. Tujuan penyuluhan ini adalah untuk memberikan bantuan keilmuan pada masyarakat mengenai kutil kelamin dan selanjutnya akan menurunkan risiko penularan serta insiden penyakit.

\section{Bahan dan Metode}

Tempat dan Waktu Pelaksanaan

Tempat penyuluhan dilaksanakan di Puskesmas Dinoyo, kecamatan Lowokwaru, Malang, pada hari Rabu, tanggal 19 April 2017. Kegiatan ini merupakan bentuk penerapan salah satu Tri Dharma Perguruan Tinggi SMF IImu Kesehatan Kulit dan Kelamin FKUB-RSSA yaitu pengabdian kepada masyarakat. Panitia yang dilibatkan telah mendapatkan Surat Tugas Dekan (ST Dekan No. 525A/ST/UN10.7/KP/2017).

\section{Khalayak Sasaran}

Penyuluhan ini ditujukan kepada pasien poliklinik Puskesmas Dinoyo, Malang dan anggota LSM di bidang Infeksi Menular Seksual dan HIV-AIDS dengan asumsi jumlah peserta sebanyak 40 orang.

\section{Metode Pelaksanaan Kegiatan}

Kegiatan penyuluhan ini diawali dengan pemberian pre test, diikuti penyampaian materi berupa ceramah tentang Kutil Kelamin dan diskusi dengan narasumber dr. Lita Setyawatie, Sp.KK. Soal yang diujikan pada peserta berupa 5 buah soal pilihan ganda. Rangkaian terakhir adalah evaluasi kegiatan. 


\section{Rancangan Evaluasi}

Evaluasi kegiatan penyuluhan ini berupa diskusi dan pengisian post test. Evaluasi dijadwalkan pada hari yang sama setelah kegiatan berlangsung. Soal pre test dan post test merupakan soal yang sama dengan pertanyaan mengenai pengetahuan tentang deteksi dini dan tatalaksana kutil kelamin yang telah disampaikan sebelumnya dalam materi. Peningkatan pengetahuan peserta penyuluhan diuji secara statistik dengan uji $\mathrm{T}$ berpasangan. Indikator keberhasilan kegiatan ini berupa peningkatan pengetahuan para peserta penyuluhan tentang deteksi dini dan tatalaksana kutil kelamin.

\section{Hasil}

Program Pengabdian Masyarakat berupa penyuluhan ini dilaksanakan di Puskesmas Dinoyo, Malang (Gambar 1). Kegiatan penyuluhan dihadiri oleh anggota LSM dan tenaga medis yang bergerak di bidang Infeksi Menular Seksual dan HIVAIDS. Pasien poliklinik sebagai salah satu sasaran yang strategis untuk program penyuluhan tidak menghadiri acara. Kemungkinan hal ini dikarenakan waktu penyuluhan yang bertepatan dengan jam pelayanan poliklinis. Asumsi jumlah peserta adalah 40 orang, dengan jumlah kehadiran 25 orang $(62,5 \%)$

Ditinjau dari segi materi yang disampaikan, banyak pengetahuan terkait kutil kelamin yang diperoleh peserta pengabdian masyarakat. Materi penyuluhan diberikan oleh narasumber dr. Lita Setyawatie, Sp.KK yang merupakan staf pengajar di Departemen/SMF IImu Kesehatan Kulit Kelamin FKUB-RSSA. Isi materi penyuluhan berupa definisi, penyebab, perjalanan penyakit, faktor risiko, cara penularan, terapi dan pencegahan kutil kelamin.

Berdasarkan pengamatan selama kegiatan pengabdian masyarakat berlangsung, dapat disimpulkan beberapa hal yaitu: (1). Para peserta menunjukkan minat dan perhatian terhadap materi yang disampaikan oleh narasumber. (2). Kegiatan diskusi berlangsung lancar, dilihat dari keaktifan para peserta yang bertanya mengenai hal-hal yang belum diketahui tentang kutil kelamin. (3). Para peserta aktif mengungkapkan masalah-masalah terkait kutil kelamin yang dialami selama ini.

Hasil evaluasi pre test menunjukkan bahwa tingkat pengetahuan peserta mengenai deteksi dini dan tatalaksana kutil kelamin masih rendah. Evaluasi terhadap serapan oleh peserta penyuluhan dilakukan melalui uji pengetahuan dengan metode pre test dan post test (Tabel 1). Dari grafik evaluasi pre test dan post test di bawah dapat dilihat adanya peningkatan pengetahuan peserta penyuluhan pada materi yang diberikan (Gambar 2).

Hasil post test menunjukkan bahwa pengetahuan peserta penyuluhan mengenai deteksi dini dan tatalaksana kutil kelamin meningkat secara signifikan. Hal ini terlihat dari perubahan signifikan $(p<0,05)$ nilai rerata uji pengetahuan (pre test dan post test) yang diikuti para peserta. Hasil uji $t$ dapat dilihat dari Tabel 2.

Pada sesi tanya jawab dan diskusi, tim pengabdian masyarakat juga memperoleh beberapa masukan yang bermanfaat yaitu mengenai kegiatan lanjutan berupa program skrining kutil kelamin dan pengobatan massal bagi masyarakat awam. Masukan lainnya yaitu perlu diadakan penyuluhan terkait IMS dan HIV-AIDS seperti keputihan, sifilis dan penyakit-penyakit IMS lainnya. 


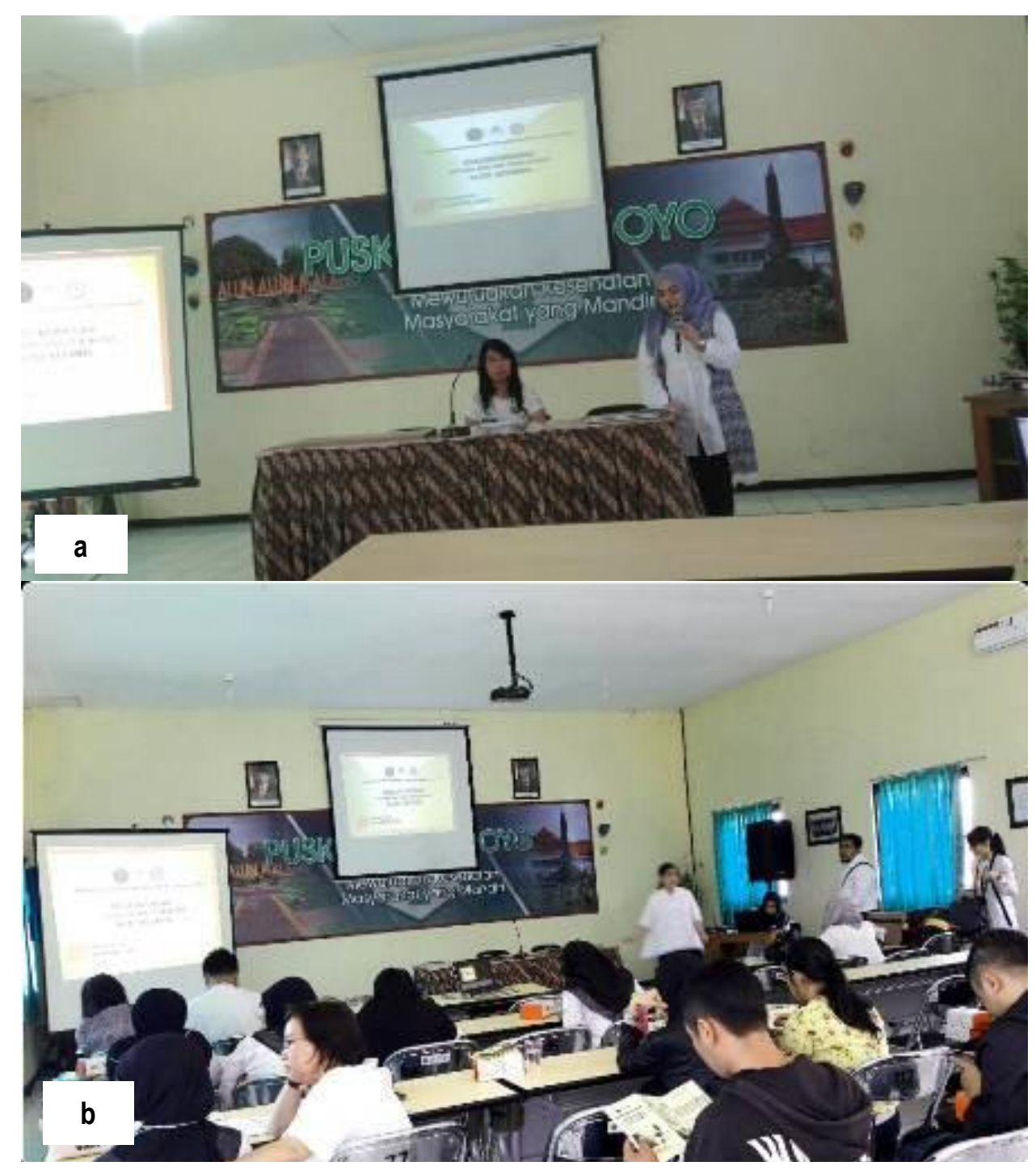

Gambar 1. (a). Penyuluhan di Puskesmas Dinoyo. Pembukaan oleh ketua panitia (1a), Penyampaian materi oleh narasumber (1b).

Tabel 1. Materi uji pengetahuan.

\begin{tabular}{ll}
\hline No. & \multicolumn{1}{c}{ Pertanyaan } \\
\hline 1. & Penyebab kutil kelamin \\
\hline 2. & Rute penularan kutil kelamin \\
\hline 3. & Metode deteksi dini kutil kelamin \\
\hline 4. & Pilihan terapi pada kutil kelamin \\
\hline 5. & Strategi pencegahan kutil kelamin \\
\hline
\end{tabular}




\section{Evaluasi pre-test dan post-test}

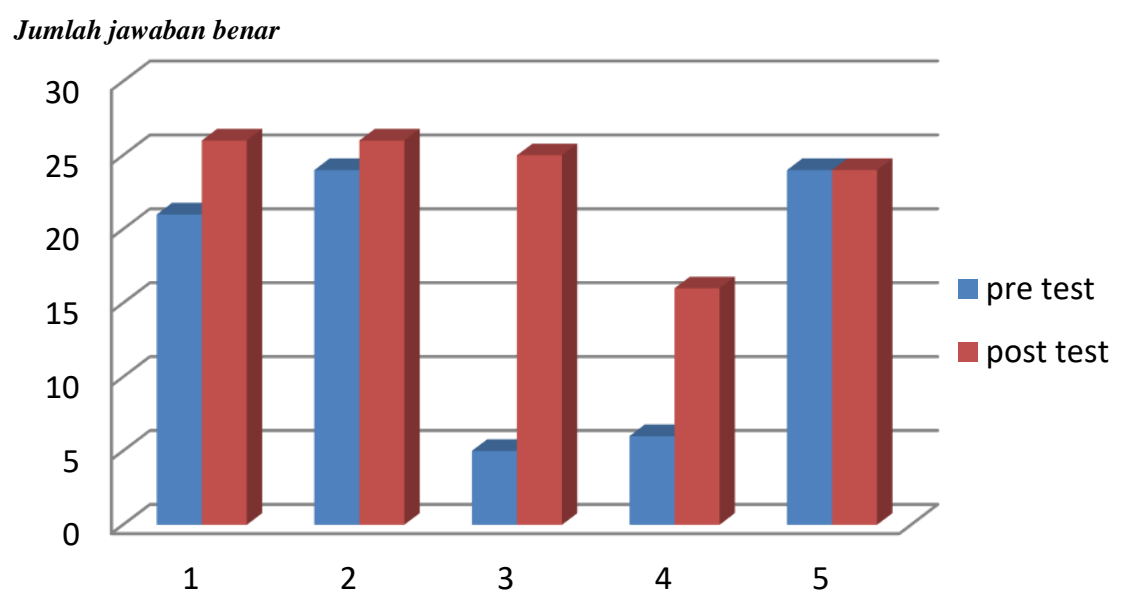

Gambar 2. Evaluasi serapan peserta penyuluhan.

Tabel 2. Perbedaan pengetahuan peserta penyuluhan .

\begin{tabular}{ccc}
\hline Pengetahuan & Sebelum & Sesudah \\
\hline $\mathrm{N}$ & 25 & 25 \\
\hline mean & 3.00 & 4.48 \\
\hline SD & 1.225 & 0.653 \\
\hline uji t & \multicolumn{3}{c}{7.007} \\
\hline P & \multicolumn{3}{c}{$0.008^{*}$} \\
\end{tabular}

${ }^{*}$ signifikan $p<0,05$

\section{Pembahasan}

Kutil kelamin merupakan penyakit IMS dengan tingkat insiden tertinggi. Kutil kelamin dapat mengenai semua jenis kelamin yang aktif secara seksual dan disebabkan oleh human papilloma virus (HPV). Prevalensi kutil kelamin menurut berbagai laporan epidemiologi meningkat dalam beberapa dekade terakhir, mungkin sebagai akibat dari perubahan perilaku seksual dan berkaitan dengan tingginya insiden HIV.1,3,4 Seperti diketahui sebelumnya, kondisi imunosupresi terkait infeksi HIV akan meningkatkan insiden infeksi oleh patogen lain, salah satunya yaitu HPV.,4 Transmisi penularan HPV dapat terjadi melalui kontak kulit dan hubungan seksual dengan faktor risiko utama seperti sering berganti pasangan dan tidak menggunakan barrier contraceptives (alat pengaman). 4,5

Penderita HIV-AIDS rentan terhadap infeksi kutil kelamin karena status imun dan pola perilaku seksual mereka. Edukasi terhadap anggota LSM dan tenaga medis yang bergerak di bidang IMS dan HIV-AIDS diharapkan efektif sebagai salah satu upaya pencegahan. Kelompok ini diasumsikan mampu menjadi lini pertama dalam konsultasi, penyuluhan, pelayanan program pemberantasan kutil kelamin. Puskesmas Dinoyo memiliki keunggulan sebagai sasaran strategis karena memiliki layanan poliklinis IMS, HIV-AIDS dan memiliki akses terhadap LSM terkait. 
Manifestasi klinis yang timbul pada kutil kelamin adalah pertumbuhan berupa kutil yang tidak menimbulkan rasa nyeri atau gatal. Lesi dapat bertangkai atau melekat di dasar dengan permukaan berjonjot (verrucous) atau datar. Area timbulnya lesi terutama pada lokasi yang terpapar hubungan seksual, dengan lokasi tersering pada area serviks dan area anal.3,4,6 Terkadang kutil kelamin pada area tersebut dapat menimbulkan perdarahan dan iritasi. Kutil kelamin pada area anal ini terutama dijumpai pada penderita HIV yang berhubungan secara anogenital (85-93\%). Lokasi anatomis yang tidak terlihat oleh pasien ini juga seringkali menyebabkan pasien tidak menyadari adanya gejala. Manifestasi pada pasien yang baru terinfeksi pada umumnya subklinis dan bersifat asimptomatik selama berbulan-bulan atau bertahun-tahun sehingga pasien dapat menularkan penyakit kepada orang lain secara tidak sadar. ${ }^{3}$ Edukasi mengenai deteksi dini kutil kelamin diharapkan cukup efektif sebagai salah satu upaya preventif terjadinya kutil kelamin.

Morbiditas terkait dengan kutil kelamin yaitu rekurensi dan risiko keganasan menjadi karsinoma in situ atau karsinoma squamosa yang bersifat invasif. ${ }^{4}$ Kutil kelamin yang dikaitkan dengan keganasan adalah yang disebabkan oleh HPV kelompok risiko tinggi karena adanya oncoprotein E6 dan E7.3,6 Rekurensi merupakan hal yang lazim dijumpai karena tidak ada satupun modalitas terapi yang dapat mengeradikasi infeksi HPV. 3,7,8 Terapi hanya bertujuan untuk mengeliminasi atau mengontrol lesi kutil kelamin dengan cara menghilangkan lesi secara kimiawi, fisika atau meningkatkan sistem imun. ${ }^{8,9}$ Insiden rekurensi ini dilaporkan memiliki kaitan dengan sistem imun, frekuensi hubungan seksual dan kebiasaan berganti-ganti hubungan seksual. ${ }^{9}$ Gejala yang ditimbulkan oleh kutil kelamin bersifat minimal sehingga kesadaran pasien untuk melakukan pengobatan cukup rendah dan pasien dapat menularkan penyakitnya kepada orang lain. Tatalaksana terhadap kutil kelamin merupakan salah satu materi yang terdapat dalam penyuluhan. Hal tersebut merupakan hal penting dan mendasar terkait penularan dan pencegahan penularan yang diharapkan mampu diketahui oleh sasaran.

\section{Kesimpulan}

Berdasarkan uraian di atas, diperoleh kesimpulan bahwa kegiatan pengabdian kepada masyarakat ini dapat meningkatkan pengetahuan para anggota LSM dan tenaga medis yang bergerak di bidang Infeksi Menular Seksual dan HIV-AIDS mengenai deteksi dini dan tatalaksana kutil kelamin.

\section{Saran}

Pelaksanaan pengabdian masyarakat ini telah berjalan sangat baik. Partisipasi peserta sangat baik (tingkat kehadiran $62.5 \%$ ). Namun demikian, masih ada beberapa kekurangan yaitu ketidakhadiran pasien poliklinis IMS Puskesmas Dinoyo sebagai salah satu khalayak sasaran. Hal ini dapat disiasati pada pelaksanaan pengabdian masyarakat selanjutnya dengan mengadakan penyuluhan setelah jam pelayanan poliklinis.

\section{Daftar Pustaka}

1. Kementerian Kesehatan Republik Indonesia. Layanan Kesehatan Masyarakat dalam Penanganan IMS dalam Pedoman Nasional Penanganan Infeksi Menular Seksual. 2015.

2. Henderson $\mathrm{Z}$, Irwin $\mathrm{KL}$, Montaño $\mathrm{DE}$, Kasprzyk D, Carlin L, Greek A, Freeman C, Barnes R, Jain N. Anogenital Warts Knowledge and Counselling Practices of US Clinicians: Result From A National Survey. Sex Transm Dis. 2007; 34(9):64452. 
3. Indriatmi W, Zubier F. Kondilomata Akuminata. Dalam: Infeksi Menular Seksual..Daili SF, Nilasari H. Makes WIB, Zubier F, Romawi R, Pudjiati SR (Editor). Edisi ke-5. Jakarta: Badan Penerbit Fakultas Kedokteran Universitas Indonesia. 2017. HIm. 176-187.

4. Chang GJ, Welton ML. Human Papillomavirus, Condylomata Acuminata, and Anal Neoplasia. Clin Colon Rectal Surg. 2004; 17(4):221-230.

5. de Camargo CC, Tascak I, Mendes MB, Miot HA, de Souza LR et al. Prevalence of Anogenital Warts in Men with HIVIAIDS and Associated Factors. The Open AIDS Journal. 2014; 8:25-30.

6. Leonard B, Kridelka F, Delbecque K. A Clinical and Pathological Overview of Vulvar Condyloma Acuminatum, Intraepithelial Neoplasia, and Squamous
Cell Carcinoma. BioMed Research International. 2014; 2014:480573.

7. Sterling JC. Human Papillomaviruses. In: Burns T, Breathnath S, Cox N, Griffiths C, (Editor). Rook's Textbook of Dermatology. $8^{\text {th }}$ Edition. Wiley-Blackwell. 2010. P. 33.37-33.51.

8. Winer RL, Koutsky LA. Genital Human Papillomavirus Infection. In: Holmes KK, Sparling PF, Stamm WE, Piot P, Wasserheit JN, Corey L, Cohen M, Watts DH, (Editor). Sexually Transmitted Disease. $4^{\text {th }}$ Edition. New York: Mc-GrawHill. 2008. P. 516-528.

9. Sung $\mathrm{HJ}$, Ahn EJ, Kwon OH, Park SH. Association of Immune Status with Reccurent Anal Condylomata in Human Immunodeficiency Virus-Positive Patients. J Korean Soc Coloproctol. 2012; 28(6):294-298. 